\title{
Food Demand Patterns in Tanzania: A Censored Regression Analysis of Microdata
}

\author{
Ananda Weliwita, David Nyange and Hiroshi Tsujii*
}

\begin{abstract}
This paper estimates price and food expenditure elasticities of demand for twelve food groups in Tanzania by applying the linearized Almost Ideal Demand system to the latest household survey data. In estimation, particular attention is paid to the presence of zero expenditure and the effects of demographic characteristics on food demand patterns. The results indicate that maize, rice, other cereals, pulses, sugar, edible oils, fish, starch, fruits and vegetables, meat, and other foods are price inelastic while milk and dairy products have unitary elasticity of demand. Most of the food groups are income elastic. The results also reveal that household income and family size have significant effects on food demand patterns. Main policy implications of the results include inter alia (a) income oriented policies will have a greater effect on promoting food consumption than price related policies, (2) a significant price decline associated with increased production of maize and rice will benefit a majority of households since the two commodities have high budget shares and low own-price elasticities of demand, and (3) meat was found to be inelastic with respect to the expenditure on food.
\end{abstract}

\footnotetext{
*The authors are, respectively, Economist in the Urban Economy and Finance Branch, United Nations Human Settlements Program, Nairobi, Kenya; Senior Lecturer in the Dept. of Agricultural Economics, Sokoine University of Agriculture, Morogoro, Tanzania, and Professor in the Natural Resource Economics Division, Graduate School of Agriculture, Kyoto University, Kyoto, Japan. The authors thank the Bureau of Statistics, the Republic of Tanzania for providing data. The manuscript was completed while the first two authors were a Visiting Research Fellow and a doctoral student, respectively, at the Graduate School of Agriculture, Kyoto University, Kyoto, Japan.
} 


\section{Introduction}

Knowledge on food demand patterns of a particular country is useful to its policy planners in addressing three major policy issues. First, it helps policy planners identify which policy interventions are most appropriate in improving the nutritional status of individuals and households. Second, it is useful in designing various food subsidy strategies that must be pursued by the government. Third, the knowledge on food demand behavior is essential for conducting sectoral and macroeconomic policy analyses (Sadoulet and de Janvry, 1995).

Central to the analysis of food consumption behavior is the estimation of price and income elasticities of food. According to the literature, primary attention has been paid in the past to the estimation of food demand elasticities in developed countries. Although a number of studies have been published on the subject in developing countries, much less effort has been made to understand food demand patterns in African countries. The handful of published studies include Nweke et al., (1994) and Njoku and Nweke (1990) on Nigeria; Deaton (1988) on Cote d'Ivoire; and Savadogo and Brandt (1988) on Burkina Faso. To the best of our knowledge, no published estimates of food demand elasticities exist for Tanzania.
The main objective of this paper is to present price and expenditure elasticities of demand for food in Tanzania. Maize is the staple food of 28 million people in Tanzania. According to the Marketing Development Bureau (1997), Tanzania annually produces about 2.6 million tons of maize. Rice is another important grain consumed particularly in the urban and rice growing rural areas. Annual paddy production is about 0.7 million tons. Small quantities of maize were imported in some years in the past to supplement the local production whereas significant quantities of rice and wheat are imported every year (about 50,000 tons each). While maize, rice and wheat are the preferred staple foods, sorghum, cassava, banana and root crops such as potato and yams are also consumed in significant quantities. According to the Ministry of Agriculture annual report (1992), among all staple foods maize is the major source of calories followed by rice. Meat is consumed mainly in pastoral and near pastoral communities and in urban areas. Fish consumption is mainly concentrated along the coast and big rivers and in communities near lakes. The data from the 1991/92 national household survey were used for the analysis. In estimation, particular attention is paid to the issue of the effects of demographic variables on food demand patterns. 
In section 2, the demand model is specified. In Section 3, the construction of variables and the estimation procedure are discussed. Section 4 presents the results. Section 5 concludes the paper.

\section{Model Specification}

In specifying the demand system we assumed that consumers allocate their expenditures in two stages. In the first stage, they decide how much to spend on each of the broad categories of goods and services such as food, housing, clothing, transportation, entertainment etc. Allocation of expenditure on individual groups is determined by consumers' total income and group price indexes (Heien and Pompelli, 1989). In the second stage, the group expenditure is allocated among various commodities in that group depending on the prices of individual commodities and the expenditure allocated to that group in the first stage. The second-stage budgeting procedure assumes weak separability of the direct utility function over the broad categories of goods (Fan et al., 1995). In this paper, we are modeling the demand for food and dealing with only the second stage of the twostage budgeting process.

The Almost Ideal Demand System (AIDS) of Deaton and Muellbauer (1980a, 1980b) was employed to model the demand for food in the second-stage. The AIDS model has been widely used for demand analysis because of its linearity and flexibility and because it satisfies the axioms of the demand theory (Heien and Wessells, 1990). The AIDS model, in budget-share form, is

$$
w_{i}=\alpha_{i}+\sum_{j} \gamma_{i j} \ln p_{j}+\beta_{i} \ln \left(\frac{X}{P}\right)
$$

where

$$
\begin{aligned}
& \mathrm{w}_{\mathrm{i}}= \text { The } i^{\text {th }} \text { budget share } \\
& p_{\mathrm{j}}= \text { Prices } \\
& \gamma_{\mathrm{ij}}= \text { Price coefficients } \\
& \beta_{\mathrm{i}}= \text { The expenditure coefficient } \\
& X= \text { The total expenditure on all } \\
& \text { commodities } \\
& P= \text { Price index defined as, } \\
& \ln P=\alpha_{0}+\sum_{j} \alpha_{j} \ln p_{j} \\
&+0.5 \sum_{i} \sum_{j} \gamma_{i j} \ln p_{i} \ln p
\end{aligned}
$$

The $\alpha$ parameters are the average budget shares when all prices and real expenditure are equal to one. The $\beta$ parameters measure the change in the $i^{\text {th }}$ budget share with respect to a change in real income, all else held constant, and indicate whether goods are necessities or luxuries. If $\beta_{\mathrm{i}}<0, \mathrm{w}_{\mathrm{i}}$ decreases when $X$ increases so that good $i$ is a necessity. Conversely, if $\beta_{\mathrm{i}}>0, \mathrm{w}_{\mathrm{i}}$ increases with $X$ so that good $i$ is a luxury. The $\gamma_{i j}$ parameter measures the change in the $i^{\text {th }}$ budget share for a unit change in $p_{\mathrm{j}}$ with real income held constant.

The demand for food is influenced by the age composition of 
the population and various other demographic variables. To capture the effects of demographic variables on food demand patterns, the intercept of equation (1) was modified by the translating method (Heien and Wessells, 1990). According to the translating method, $\alpha_{i}$ was modified as

$$
\begin{gathered}
\alpha_{i}=\rho_{i 0}+\sum_{k=1}^{s} \rho_{i k} d_{k} \\
i=1, \ldots, n
\end{gathered}
$$

where $d_{k}$ are demographic variables of which there are $s$ and $\rho_{\mathrm{i} 0}$ and $\rho_{\mathrm{ik}}$ are parameters to be estimated.

Incorporating (3) into (1) will yield

$$
\begin{aligned}
w_{i} & =\rho_{i 0}+\sum_{k=1}^{s} \rho_{i k} d_{k} \\
& +\sum_{j} \gamma_{i j} \ln p_{j}+\beta_{i} \ln \left(X / P^{*}\right)
\end{aligned}
$$

where $P^{*}$ is the Stone price index defined as

$$
\ln P^{*}=\sum_{i} w_{i} \ln p_{i}
$$

The model in (4) is a linear approximation (LAIDS) to the AIDS model in (1) which is intrinsically nonlinear.
The Marshallian demand elasticities [equations (6) and (7)] and Hicksian demand elasticities [equations (8) and (9)] were computed using the estimated parameters of the LAIDS model (Hayes et al., 1990). ${ }^{1}$

$$
\begin{aligned}
& \varepsilon_{i i}=-1+\frac{\gamma_{i i}}{w_{i}}-\beta_{i} \\
& \varepsilon_{i j}=\frac{\gamma_{i j}}{w_{i}}-\beta_{i}\left(\frac{w_{j}}{w_{i}}\right) \\
& \delta_{i i}=-1+\frac{\gamma_{i i}}{w_{i}}+w_{i} \\
& \delta_{i j}=\frac{\gamma_{i j}}{w_{i}}+w_{j}
\end{aligned}
$$

The expenditure elasticities were computed using

$$
\eta_{i}=1+\frac{\beta_{i}}{w_{i}}
$$

\section{Data and Estimation Procedure}

A total of 142 food items were aggregated into 12 groups: maize, rice, other cereals, pulses, milk and dairy products, sugar, edible oils, fish, starch, fruits and vegetables, meat, and other foods. The data for the analysis were taken from the household budget survey conducted between December 1991 and

${ }^{1}$ These are the elasticity formulae for the AIDS model. Green and Alston (1990, 1991) provide elasticity formulae for the LAIDS model. Buse (1994) presents alternative formulae to the Green-Alston elasticities. However, he shows that neither his nor the Green-Alston elasticities are superior to the conventional AIDS elasticity formulae. 
November 1992 by the Bureau of Statistics, the United Republic of Tanzania. Households for the survey were selected from the National Master Sample (NMS) which is nation-wide covering both rural and urban areas. The NMS consists of 222 clusters, 100 clusters or villages representing rural areas and 122 clusters or Enumeration Areas (EAs) representing urban areas. While village is the primary sampling unit for rural areas, EA is the primary sampling unit for urban areas. The 122 EAs consist of 52 from the city of Dar-es-Salaam, 40 from the 9 municipalities (Arusha, Dodoma, Iringa, Mbeya, Morogoro, Moshi, Mwanza, Tabora, and Tanga), 10 from remaining regional headquarters (one each from Bukoba, Kibaha, Kigoma, Lindi, Mtwara, Musoma, Shinyanga, Singida, Songea, Sumbawanga), and 20 from the remaining district headquarters and other small towns. The households were sampled using systematic simple random sampling within the cluster. Twenty four households, 2 households per month for 12 months, were initially chosen to be surveyed from each cluster making the total number of households surveyed to be 5328 . However, out of this only 4994 households participated in the actual survey. From this, 90.1 percent had full response, thus, making the final sample consisting of 4800 households.
Descriptive statistics of the variables are presented in appendix table 1. Among all food groups, maize accounts for the highest budget share and the mean expenditure reflecting the fact that it is the staple food in Tanzania. A typical Tanzanian diet consists of ugali, a stiff maize porridge. In urban areas, people usually eat ugali for lunch and rice for supper. Unlike maize, which is grown almost everywhere in the country, rice farming is limited only to lowland areas and river valleys. Since local production cannot meet the domestic demand for rice some rice is imported annually making it more expensive than maize. The budget share for starch is much smaller than that for most food grains. This reflects the fact that consumer tastes are shifting away from traditional foods such as cassava, yams, and banana toward food grains. Except maize, rice, and the other food group, meat accounts for the largest budget share. Meat has the highest unit value among all food groups and is mainly consumed in pastoral communities, in rural areas that grow export crops, and in urban areas. Meat is less affordable to the urban poor and non-pastoral non-growers of export crops. While the high price of meat is mainly due to the high transportation cost of livestock and lack of refrigeration facilities for storage, the high price of rice is due to the low domestic production and the high cost of imports. Industrial processed foods such as sugar and 
edible oils too have high unit values. On average, budget shares indicate a broad diversity of diet as none of the food groups, including maize, accounts for more than 19 percent of the total food budget. The budget share for all food grains is 37 percent.

The following demographic variables were incorporated into equation (4): (1) sex of the head of the household (a dummy variable taking value 1 for female and 0 for male), (2) location (a dummy variable taking value 1 for rural and 0 for urban), (3) family income (two dummy variables one taking value 1 for low income and 0 for middle and high income and the other dummy variable taking value 1 for middle income and 0 for low and high income), (4) number of male household members between ages of $0-5,6-11,12-17,18-65$ and over 65 years, and (5) number of female household members between ages of $0-5,6-11,12-17,18-65$ and over 65 years.

Since actual market prices of commodities were not collected in the survey, we had to use the unit values (expenditure divided by quantities) as proxies for 'prices'. Like in many other studies (for example, Jensen and Manrique, 1998; Abdulai et al., 1999), unit values for commodity groups were calculated by summing the unit values of individual food items which were weighted by the corresponding budget shares. For some households, expenditures for some commodities were found to be zero, so unit values for these commodities could not be calculated. The zero expenditure indicates nonpurchases due to nonpreference, sufficient household inventory, or responses to market prices (Cheng and Capps, 1988). The zero unit values were replaced by the cluster averages of the nonzero unit values for commodities and commodity groups (Laajimi et al., 1997).

The participation rate, which is defined as the proportion of the total sample that has a nonzero consumption of a particular commodity, for each of the twelve food groups are presented in table 1 . Note that some commodity groups i.e., milk and dairy products, sugar, edible oils, and starch have relatively low participation rates (less than 90 percent) compared to the other groups. Low participation rates mean the presence of a large number of zeros for the budget shares which cause the disturbances associated with those variables to have a nonzero mean. Hence, the use of standard estimation methods will result in biased and inconsistent parameter estimates because such methods do not take into account the nonzero mean of the disturbances (Wales and Woodland, 1989; Maddala, 1983). The presence of zero expenditure for some items for some households is a common feature in household budget data. 
Several methods have been proposed to deal with the zero expenditure problem (for a brief review on alternative approaches see Jensen and Manrique, 1998). In this paper, we employed the two-step procedure adopted in Heien and Wessells (1990). The method involves a model in which the dependent variables are censored. According to this method, the zero expenditure problem is modeled as a two-stage decision process. In the first stage, consumers decide whether to purchase some amount of a particular good or not and in the second stage they decide on the amount they buy. Thus, the dependent variables (budget shares) take the value 0 when consumer expenditure on a particular good is zero and a positive value when the expenditure is nonzero. This dichotomy in the decision to buy or not to buy in the first stage can be expressed as a dummy variable.

The first step in this method involves estimating a probit regression for each of the 11 food groups except the other food group, which was deleted from the system. The parameters of the probit regressions are then used to compute the inverse Mill's ratio $(\Phi)$ for each household for each food group. The $\Phi$ for each food group is then used as an instrument in the respective equation of the system in (4). The probit regressions take the form

$$
P_{i h}=f\left(p_{1}, \ldots, p_{j}, X, d_{1}, \ldots, d_{s}\right)
$$

where $P_{\text {ih }}$ is 1 if the $h^{\text {th }}$ household buys the $i^{\text {th }}$ food item and 0 if it does not. The other variables are as defined before. The maximum likelihood estimates from equation (11) are then used to construct the inverse Mill's ratio for each household for each food group. The inverse Mills's ratio for the $h^{\text {th }}$ household that consumes the $i^{\text {th }}$ item is derived as

$\Phi_{i h}=\frac{\theta\left(p_{l}, \ldots p_{j}, X_{\left.d_{l}, \ldots, d_{s}\right)}\right.}{\Theta\left(p_{l}, \ldots p_{j}, X_{d_{l}, \ldots, d_{s}}\right)}$

where $\theta$ and $\Theta$ are the standard normal density and the cumulative probability functions, respectively. The inverse Mill's ratio for a household that does not consume the $i^{\text {th }}$ item is derived from

$$
\Phi_{i h}=\frac{\theta\left(p_{1}, \ldots, p_{j}, X, d_{l}, \ldots, d_{s}\right)}{1-\Theta\left(p_{l}, \ldots, p_{j}, X, d_{l}, \ldots, d_{s}\right)}
$$

The inverse Mill's ratio for each household for each item is then used as an instrument in equation (4). So the estimating model is

$$
\begin{aligned}
w_{i}= & \rho_{i 0}+\sum_{k=1}^{s} \rho_{i k} d_{k}+\sum_{j} \gamma_{i j} \ln p_{j} \\
& +\beta_{i} \ln \left(X_{\text {Over }} \stackrel{*}{P}\right) \\
& +\omega_{i} \Phi_{i h^{+}}+\varepsilon_{i}
\end{aligned}
$$


where $\varepsilon_{\mathrm{i}}$ is the econometric error term. However, Heien and Wessells (1990) point out that even if the parameter estimates are invariant to the equation deleted, if all $n$ equations are specified as (14), then the system will not add up. If all $n$ equations are specified as in (14), the adding up condition will require that $\omega_{\mathrm{i}} \Phi_{\mathrm{ih}}=0$. Because $\Phi_{\mathrm{ih}}$ can assume any value, this restriction is impossible. However, Heien and Wessells (1990) state that the adding up constraint could be preserved by specifying the deleted equation as follows:

$$
\begin{aligned}
w_{i}= & \rho_{i 0}+\sum_{k=1}^{s} \rho_{i k} d_{k} \\
& +\sum_{j} \gamma_{i j} \ln p_{j}+\beta_{i} \ln \left(X / P^{*}\right) \\
& +\omega_{i} \Phi_{i h^{-}} \sum_{j=1}^{n-1} \omega_{i} \Phi_{i h}+\varepsilon_{i} .
\end{aligned}
$$

To be consistent with the demand theory, the following restrictions are imposed on equation (14):

$\sum_{j} \gamma_{i j}=0$ (homogeneity),

$\gamma_{i j}=\gamma_{j i}$ (symmetry), $\sum_{i} \alpha i=1 \quad \sum_{i} \gamma_{i j}=0 \quad \sum_{i} \beta_{i}=0$

(adding up restriction)

The demand system in (14) was estimated by nonlinear ITSUR technique together with homogeneity and symmetry restrictions imposed ${ }^{2}$. The adding up condition makes the contemporaneous covariance matrix singular so one equation (other food group) was dropped from the system. The variance of the elasticities was computed at the mean budget shares. The variance for the elasticities and the coefficients of the omitted equation were calculated using the formula for the distribution of a linear transformation of a normally distributed random vector.

\section{Results and Discussion}

The parameter estimates of the demand system are presented in appendix table 2 . The poor fit of the equations as measured by the low $\mathrm{R}^{2}$ is not unusual when models are estimated with cross sectional data. of a total of 365 coefficients, 135 coefficients (or 37 percent) are statistically significant at the 5 percent level. More than half of the price coefficients are significant at the 5 percent level. Except for rice,

\footnotetext{
${ }^{2}$ Some researchers have empirically tested for the validity of the two restrictions. Here we have not tested for their validity. Instead, we directly imposed them on the system because they are implied by demand theory. Probit regressions were carried out using Econometric Views (Eviews ) version 2.0 software. After estimating a probit model, Eviews stores the inverse Mill's ratio for each observation under the series named RESID. The LAIDS model was estimated using SAS (version 6).
} 
and milk and dairy products, all the other own price coefficients are significant at the 1 percent level. The parameter estimates for the inverse Mill's ratio for all the equations are statistically significant at the 1 percent level which confirms that estimating the system ignoring the presence of zeros for the budget shares would result in biased and inconsistent parameter estimates.

The expenditure coefficients for all food groups, except maize, pulses, and starch, are statistically significant at the 1 percent level. The coefficients for rice, milk and dairy products, sugar, edible oils, and meat are negative implying that they are necessities while the positive coefficients for other cereals, fish, fruits and vegetables, and other foods imply that they are luxuries ${ }^{3}$. Considering fish, fruits and vegetables as luxuries is not unusual for a low income country since priority is given to foods that are sources of energy. Exception to this trend is meat, which is mostly consumed in the urban and pastoral communities. Other cereal and cereal products group is considered a luxury since it includes bread and other wheat products such as pasta and corn flakes consumed mainly in the urban areas. Nearly half of the wheat is imported and thus expensive. Relatively cheap sorghum, millet and oats are also included in this group. However, they may have low budget shares and thus overshadowed by wheat products. The female-headed households consume less rice. This may be due to the fact that femaleheaded households usually have lower incomes than the male-headed households. On the other hand, the female-headed households consume more of the other foods than male headed households. Apart from this, the sex of the head of the household has no significant effect on the consumption of other food categories.

The coefficients for the location dummies indicate that rural people consume more maize, pulses, milk and dairy products, and starch and less rice, other cereals, sugar, edible oils, fruits and vegetables, and other foods than their urban counterparts. The coefficients for the dummy variables for income indicate that people in the low income category consume more of maize, pulses, and fruits and vegetables and less of milk and dairy products, edible oils, meat, and other foods compared to those in the higher income group. People in the low and middle-income groups consume more milk and dairy products and edible oils than those in the high-income group.

${ }^{3}$ Other foods group includes soda, beer, away-from-home meals, canned foods, spices and raw materials for baking. Such food items are less affordable to low income households. 
The coefficients for the interaction terms for the dummy variables reveal that families in the low income group that are headed by females have a negative effect on the consumption of other foods. The coefficients for the interaction terms between rural and low income indicate that being rural and poor have a positive effect on the consumption of other cereals, pulses, edible oils, fish, starch, and fruits and vegetables and a negative effect on the consumption of other foods. It is important to note here our previous finding that neither those who live in rural areas irrespective of their income level nor those who are poor irrespective of their location have a significant effect on the consumption of fish. However, being rural and poor does seem to have a positive correlation with the consumption of fish. This could be due to the fact that fish, which is a much cheaper source of protein than meat, is more readily available in rural areas. On the other hand, rural people in both low and middle-income groups tend to consume more edible oils than their counterparts in the high-income category. Given our previous finding that people who live in rural areas belonging to all income groups and those in the low income group irrespective of their location consume less of edible oils, this is an observation hard to explain. It may be that due to the high cost of meat, the rural poor are consuming more edible oil to make their less diversified foods more palatable.
Moreover, like those in the lowincome group, the rural people in the middle income group also consume more of starch, a cheaper source of carbohydrates, and less of other foods. Furthermore, we find that the rural poor families headed by females have a negative effect on meat consumption Households that have children of either sex in the 0-5 years age group have positive correlation with the consumption of milk and dairy products, and sugar, and a negative correlation with the consumption of other foods. Moreover, households that have boys in this age group have a positive relationship with the consumption of maize. As the number of children of either sex in the 6-11 years age group increases, the consumption of other food decreases, while the number of girls in this age group has a positive correlation with the consumption of other cereals and a negative correlation with the consumption of edible oils. On the other hand, as the number of boys in the same age group increases the consumption of rice increases. The number of family members in the 12-17 years age group has a negative correlation with the other food group for both sexes, while the number of boys in this age group seems to have a direct effect on the consumption of maize. In the 18-65 years age group, as the number of females increase, the consumption of rice increases while that of pulses and other foods decreases. On the other hand, the number of males has a positive correlation with the 
consumption of milk and dairy products in this age group. Finally, in the over 65 year age category, maize consumption of both sexes increases with the number of family members. While the number of females is negatively correlated with the consumption of sugar, edible oils, and other foods, the number of males has a positive correlation with the consumption of sugar and negative correlation with the consumption of meat and other foods. In general, with the increase in the number of household members in most age groups among males, the consumption of maize increases while the consumption of foods in the other food group decreases. That is quite understandable as maize is the staple food while the other food group contains items that are likely to be given the least priority as food demand increases with the expanding family.

The own - price elasticities and expenditure elasticities are presented in appendix table 3 . The cross-price elasticities are presented in the appendix table 4. The expenditure elasticities for all food groups are positive implying that all food categories are normal goods and an increase in income will generally lead to higher consumption. Although point estimates for other cereals, pulses, fish, starch, fruits and vegetables, and other food are all greater than unity, estimates for pulses and starch are not statistically different from unity. The estimate for maize also is not statistically different from one. On the other hand, estimates for rice, milk and dairy products, sugar, edible oils, and meat are all less than one. These results imply that increase in any future expenditure on food will result in less than proportionate increase in the expenditure on rice, milk and dairy products, sugar, edible oils, and meat and a proportionate increase in the expenditure of maize, pulses, and starch. Conversely, increase in any future total food expenditure will have more than proportionate increase in the expenditure shares of other cereals, fish, fruits and vegetables, and other foods. The marginal expenditure share, which is defined as the product of the expenditure elasticity and the budget share, for each food category is also presented in appendix table 3 . The results indicate that there would not be any substantial change in food demand patterns following an increase in future total expenditure on food. Maize, which accounts for the largest expenditure share will remain more or less at the same level. A slight increase in the consumption of rice, milk and dairy products, and meat could occur following increase in future total food expenditures.

The uncompensated own price elasticity estimates for all food groups are significantly different from zero at the 1 percent level and carry the expected negative sign. The estimates for all food groups are 
significantly less than one except for milk and dairy products for which the estimate is not significantly different from one. The estimates vary from -0.846 for other cereals to -1.012 for milk and dairy products. The estimates for grains vary from -0.846 for other cereals to -0.9 for rice. Rice is more elastic than maize. The own price elasticity estimates for non staples are also similar to those for staples and vary between -1.012 for milk and dairy products and -0.885 for edible oils. The estimates for the uncompensated cross-price elasticities are fairly low in all cases, but some are statistically significant indicating that some food groups are gross substitutes while the others are gross complements. In general, the demand for a particular food category is more responsive to its own price than to cross-prices. The compensated price elasticity is a better measure of substitutability between two goods because it measures only the substitution effect leaving the income effect out. All compensated own price elasticities are negative but smaller than the corresponding uncompensated price elasticities. The estimates vary between -0.713 for maize and -0.987 for milk and milk products. Unlike uncompensated cross-price elasticity estimates, the compensated cross price elasticity estimates indicate that except for other cereals and milk and milk products, all the other food groups have substitutable relationships with each other. For some cross-price elasticities, while
Marshallian estimates are negative Hicksian estimates are positive. This suggests that the income effect in these cases outweigh the substitution effect.

As mentioned previously, empirical studies on food demand analysis in African countries are quite scant relative to other developing countries in Asia and Latin America. Even the few published studies have a limited scope in the analysis. Some studies have limited their attention either to a specific region or regions of a country or to consumers belonging to certain income groups, while others have examined the food consumption behavior only of selected food groups in the country of interest. These facts make it difficult to make a meaningful comparison of our results with those of previously mentioned studies.

\section{Summary and Policy Implications}

Reliable estimates of price and income elasticities of food are critical parameters in developing models for food policy analysis. In the absence of published estimates of food demand elasticities, model builders and policy analysts in Tanzania must have relied upon subjective judgement or unpublished elasticity estimates. Applying a demand model, which is grounded in a well-structured theoretical and analytical framework to data from the latest household budget survey, 
this paper estimates price and expenditure elasticities for twelve food groups in Tanzania. In estimating the demand system, particular attention was paid to the zero expenditure problem and the effects of demographic characteristics on the demand for foods.

Major findings of the study and policy implications drawn from these findings are as follows:

(A) Food demand is quite responsive to the changes in own prices, income, and household demographics such as age and sex. For any food policy to be effective in alleviating the problems of food insecurity and malnutrition, attention must be paid to these factors.

(B) Most food commodities are inelastic with respect to the own price but elastic with respect to the expenditure on food. This suggests that, in general, income oriented policies will have a greater effect on promoting food consumption than price related policies.

(C) A substantial price decline associated with increased production of maize and rice will benefit the majority of households since the two commodities have high budget shares and low own price elasticities of demand.

(D) Unlike in many studies on other developing countries, meat is inelastic with respect to expenditure, implying that it is not a luxury (a similar finding is reported in the Savadogo Brandt study on Burkina Faso). The inelastic demand for meat can be partly attributed to the high consumption of meat in many ethnic pastoral communities such as Maasai and Sukuma. Besides pastoralists, many farmers in Tanzania practice mixed farming where they grow crops and raise livestock together. According to the 1996 National Agricultural Census, there were over 15 million cattle, 10 million goats, and 3 million sheep in Tanzania. In addition, it has been estimated that $37 \%$ of all agricultural households in Tanzania raise livestock. These facts highlight the need to incorporate the meat sector as an integral part of the national food policy. Most current food policies have limited their attention to the promotion of cereal production in general and maize production in particular.

(E) Tanzania is one of many countries that suffer from the problem of severe child malnutrition. According to the results of this study, the demand for milk increases with the number of children in the $0-5$ years age group. Although milk is an important food for everyone and to children in this age group in particular, the milk and dairy products group has the smallest budget share among all food groups. The fact that milk and dairy products are inelastic with respect to food expenditure but unitary elastic with 
respect to its own price indicates that consumers of milk and dairy products are more responsive to price than to income. Although there are 15 million cattle in Tanzania, only 1.4 percent of them is hybrid dairy cattle. The rests are indigenous breeds that yield very low amounts of milk. Any effort geared to alleviate the child malnutrition problem should place a high priority on promoting not only the production of milk but also the consumption of milk.

\section{References}

Abdulai, A., D. K. Jain, and A. K. Sharma. (1999). Household Food Demand Analysis in India. Journal of Agricultural Economics. 50:316-327.

Buse, A. (1994). Evaluating the Linearized Almost Ideal Demand System. American Journal of Agricultural Economics. 76:781-793.

Cheng, H., and O. Capps. (1988). Demand Analysis of Fresh and Frozen Finfish and Shellfish in the United States. American Journal of Agricultural Economics. 70: 533-542.

Deaton, A., and J. Muellbaur. (1980a). An Almost Ideal Demand System. American Economic Review. 70:312-326.
. (1980b). Economics

and Consumer Behavior.

Cambridge: Cambridge

University Press.

Deaton, A. (1988). Quality, Quantity, and Spatial Variations of Price. American Economic Review. 78:418-430.

Fan, S., Wailes, E. J., and G. L. Cramer. (1995). Household Demand in Rural China: A Two-Stage LES-AIDS Model. American Journal of Agricultural Economics. 77:54-62.

Green, R., and J. M. Alston. (1990). Elasticities in AIDS Models. American Journal of Agricultural Economics. 72:442-445. (1991). Elasticities in AIDS Models: A Clarification and Extension. American Journal of Agricultural Economics. 73:874-875.

Hayes, D. J., Wahl, T. I., and G. W. Williams. (1990). Testing Restrictions on a Model of Japanese Meat Demand. American Journal of Agricultural Economics. 72:556-566. 
Heien, D., and G. Pompelli. (1989). The Demand for Alcoholic Beverages: Economic and Demographic Effects. Southern Economic Journal. 55:759-770.

Heien, D., and C. R. Wessells. (1990). Demand System Estimation with Microdata: A Censored Regression Approach. Journal of Business and Economic Statistics. 8:365-371.

Jensen, H. H., and J. Manrique. (1998). Demand for Food Commodities by Income Groups in Indonesia. Applied Economics. 30:491-501.

Laajimi, A., Gracia, A., and L. M. Albisu. (1997). The Demand for Food in Spain: Economic and Demographic Effects. Journal of International Food and Agribusiness. 9:1-17.

Maddala, G. S. (1983). Limited Dependent and Qualitative Variables in Econometrics. Cambridge: Cambridge University Press.

Marketing Development Bureau. (1997). Industry Review of Maize, Rice, and Wheat. Dar es Salaam, Tanzania.
Ministry of Agriculture. (1992). Comprehensive Food Security Program. Main Report.Volume1. Dar es Salaam, Tanzania.

Njoku, J. E., and F. I. Nweke. (1990). Demand Elasticities for Food in Nigeria: The Case of Meat in IMO State. Journal of Rural Development. 13:6574.

Nweke, F. I., Okorji, E. C., and D. J. King. (1994). Expenditure Elasticities of Demand for Major Food Items in South East Nigeria. Tropical Agriculture. 71:229-235.

Sadoulet, E., and A. de Janvry (1995). Quantitative Development Policy Analysis. Johns Hopkins University Press.

Savadogo, K., and J. Brandt. (1988). Household Food Demand in Burkina Faso: Implications for Food Policy. Agricultural Economics. 2:345-364.

Wales, T. J., and A. D. Woodland. (1989). Estimation of Consumer Demand Systems with Binding Non-negativity Constraints. Journal of Econometrics. 21:263-285. 
Appendix

Table 1: Descriptive Statistics of the Variables

\begin{tabular}{lccrrrrr}
\hline $\begin{array}{l}\text { Budget } \\
\text { Share }\left(\mathrm{w}_{\mathrm{i}}\right)\end{array}$ & $\begin{array}{l}\text { Unit } \\
\left(\mathrm{p}_{\mathrm{i}}\right)\end{array}$ & Values & \multicolumn{2}{l}{ Expenditure $\left(\mathrm{X}_{\mathrm{i}}\right)$} & \multicolumn{2}{l}{ Participation } & \\
\hline \multicolumn{1}{c}{ Variable } & Mean & St dev & \multicolumn{1}{l}{ Mean } & St dev & Mean & St dev & Rate \\
Maize & 0.183 & 0.164 & 74.12 & 50.21 & 3979 & 9452 & 92.2 \\
Rice & 0.105 & 0.094 & 44.78 & 67.97 & 2289 & 5430 & 82.0 \\
Other Cereals & 0.084 & 0.107 & 53.12 & 59.31 & 1817 & 3647 & 92.2 \\
Pulses & 0.054 & 0.066 & 82.59 & 62.59 & 1169 & 3048 & 92.3 \\
Dairy & 0.032 & 0.061 & 90.09 & 64.92 & 706 & 2078 & 55.2 \\
Sugar & 0.052 & 0.052 & 173.15 & 85.78 & 1129 & 1917 & 78.8 \\
Edible Oils & 0.038 & 0.042 & 123.52 & 176.33 & 843 & 1522 & 81.5 \\
Fish & 0.061 & 0.068 & 80.01 & 101.44 & 1317 & 3457 & 89.9 \\
Starch & 0.072 & 0.109 & 54.87 & 65.82 & 1577 & 2721 & 84.9 \\
Fruits \& Veg & 0.084 & 0.067 & 27.88 & 51.69 & 1815 & 3613 & 98.7 \\
Meat & 0.101 & 0.082 & 255.76 & 217.88 & 2194 & 3922 & 90.2 \\
Other Foods & 0.129 & 0.146 & 62.06 & 87.92 & 2793 & 6334 & 100.0 \\
\hline
\end{tabular}


Table 2.: Parameter Estimates of the Food Demand System for Tanzania Using the Censored-Regression Method

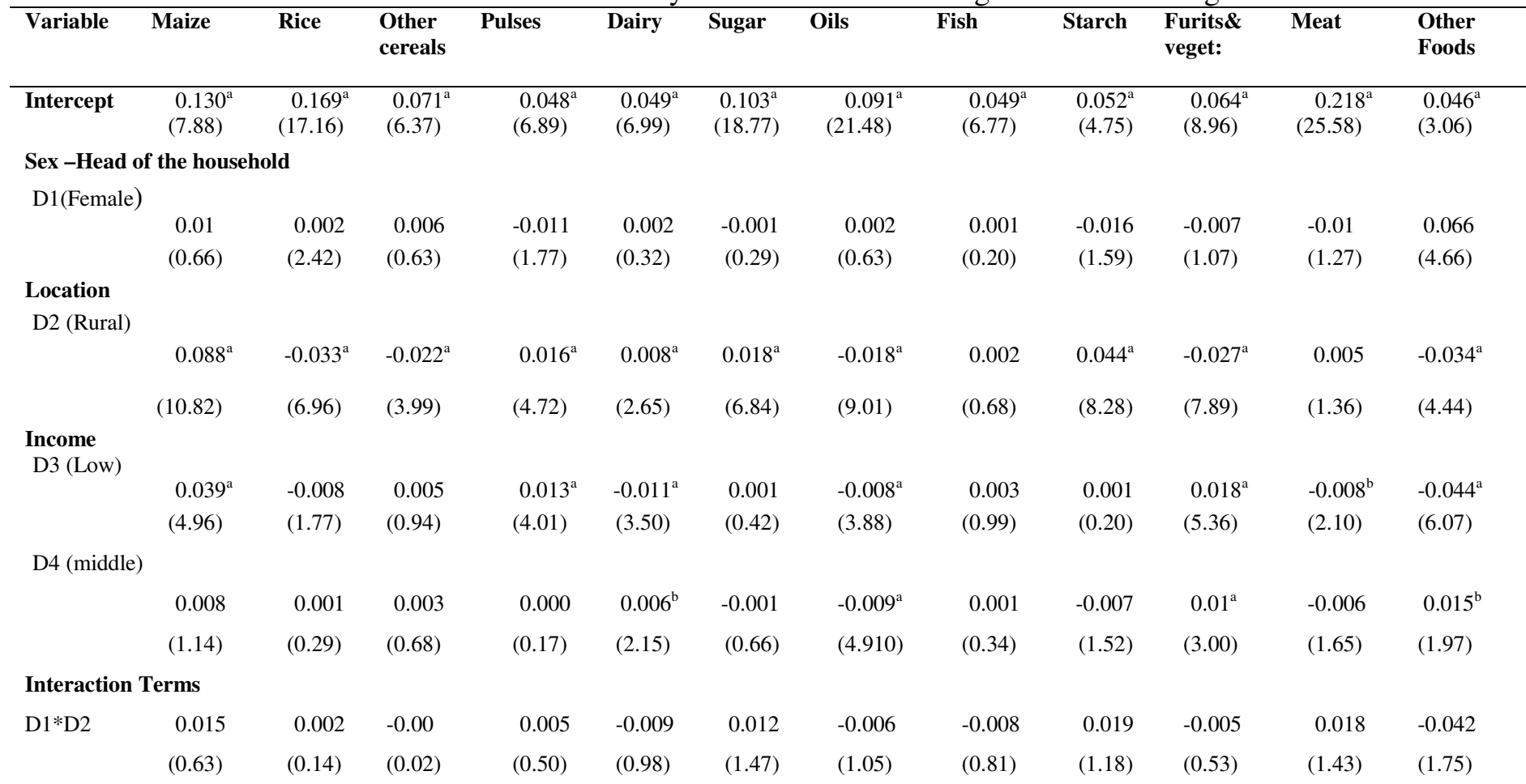




\begin{tabular}{|c|c|c|c|c|c|c|c|c|c|c|c|c|}
\hline \multirow[t]{2}{*}{ D1*D3 } & 0.026 & 0.009 & -0.01 & 0.013 & 0.010 & 0.005 & -0.004 & -0.003 & 0.014 & 0.014 & 0.01 & $-0.086^{\mathrm{a}}$ \\
\hline & $(1.35)$ & $(0.84)$ & $(0.77)$ & $(1.57)$ & (1.29) & $(0.87)$ & $(0.86)$ & $(0.43)$ & (1.09) & (91.75) & $(1.02)$ & (4.79) \\
\hline \multirow[t]{2}{*}{ D1*D4 } & -0.000 & 0.017 & -0.01 & 0.005 & 0.001 & -0.001 & -0.007 & $-0 . .009$ & 0.013 & 0.006 & -0.005 & -0.009 \\
\hline & $(0.02)$ & $(1.47)$ & $(0.73)$ & $(0.65)$ & $(0.12)$ & $(0.25)$ & $(1.36)$ & $(1.08)$ & $(0.97)$ & $(0.68)$ & $(0.47)$ & $(0.48)$ \\
\hline \multirow[t]{2}{*}{$\mathrm{D} 2 * \mathrm{D} 3$} & -0.015 & -0.004 & $0.036^{\mathrm{a}}$ & $0.011^{\mathrm{a}}$ & 0.001 & -0.000 & $0.006^{\mathrm{b}}$ & $0.015^{\mathrm{a}}$ & $0.036^{\mathrm{a}}$ & $0.02^{\mathrm{a}}$ & -0.01 & $-0.097^{\mathrm{a}}$ \\
\hline & $(1.29)$ & $(0.62)$ & (4.66) & $(2.39)$ & $(0.25)$ & $(0.15)$ & $(2.16)$ & $(3.08)$ & (4.77) & (4.06) & (1.69) & (8.84) \\
\hline \multirow[t]{2}{*}{$\mathrm{D} 2 * \mathrm{D} 4$} & 0.005 & -0.004 & 0.014 & 0.008 & 0.002 & 0.002 & $0.012^{\mathrm{a}}$ & 0.002 & $0.052^{\mathrm{a}}$ & 0.003 & -0.006 & $-0.092^{\mathrm{a}}$ \\
\hline & $(0.46)$ & $(0.64)$ & (1.91) & $(1.71)$ & $(0.460)$ & $(0.70)$ & $(4.17)$ & $(0.49)$ & (6.94) & $(0.67)$ & (1.11) & (13.38) \\
\hline \multirow[t]{2}{*}{$\mathrm{D} 1 * \mathrm{D} 2 * \mathrm{D} 3$} & -0.027 & -0.000 & 0.039 & 0.039 & -0.008 & -0.016 & 0.004 & 0.003 & -0.021 & 0.018 & $-0.033^{\mathrm{b}}$ & 0.042 \\
\hline & $(0.87)$ & $(0.01)$ & (1.84) & $(0.06)$ & $(0.64)$ & (1.63) & $(0.56)$ & $(0.28)$ & (1.06) & (1.35) & $(2.08)$ & (1.34) \\
\hline \multirow[t]{2}{*}{$\mathrm{D} 1 * \mathrm{D} 2 * \mathrm{D} 4$} & -0.027 & -0.003 & 0.042 & -0.011 & 0.016 & -0.006 & 0.009 & 0.015 & -0.021 & 0.009 & -0.019 & 0.049 \\
\hline & $(0.83)$ & $(0.18)$ & (1.84) & $(0.78)$ & (1.26) & $(0.57)$ & (1.18) & (1.09) & $(0.94)$ & $(0.65)$ & (1.14) & $(1.60)$ \\
\hline \multicolumn{13}{|c|}{$\begin{array}{l}\text { No of female Household Members } \\
\text { between ages of }\end{array}$} \\
\hline & 0.004 & -0.003 & 0.001 & 0.000 & $0.005^{\mathrm{a}}$ & $0.001^{\mathrm{b}}$ & 0.001 & -0.000 & -0.000 & -0.000 & -0.001 & $-0.01^{\mathrm{a}}$ \\
\hline & $(1.58)$ & (1.8) & $(0.61)$ & $(0.77)$ & (4.3) & (1.97) & $(1.37)$ & $(0.16)$ & $(0.29)$ & $(0.01)$ & $(0.74)$ & $(3.66)$ \\
\hline \multirow[t]{2}{*}{ 6-11 } & 0.003 & 0.002 & $0.005^{\mathrm{a}}$ & 0.00 & 0.000 & -0.00 & $-0.001^{b}$ & 0.001 & 0.001 & -0.002 & -0.002 & $-0.008^{\mathrm{b}}$ \\
\hline & (1.09) & $(1.38)$ & (2.59) & $(0.32)$ & $(0.69)$ & $(0.83)$ & $(2.23)$ & (1.45) & $(0.74)$ & (1.67) & (1.84) & (2.92) \\
\hline \multirow[t]{2}{*}{$12-17$} & 0.004 & 0.000 & 0.002 & 0.001 & 0.000 & -0.00 & 0.000 & -0.002 & 0.000 & 0.000 & 0.001 & $-.007^{\mathrm{a}}$ \\
\hline & (1.5) & $(0.46)$ & (1.01) & $(0.93)$ & $(0.43)$ & (0.09) & $(0.02)$ & (1.79) & $(0.06)$ & $(0.17)$ & (1.12) & $(2.48)$ \\
\hline \multirow[t]{2}{*}{$18-65$} & -0.002 & $0.004^{\mathrm{a}}$ & 0.001 & $-0.002^{\mathrm{b}}$ & -0.000 & -0.000 & -0.000 & 0.000 & 0.003 & 0.001 & 0.001 & $-.005^{\mathrm{b}}$ \\
\hline & (1.12) & $(2.86)$ & $(0.7)$ & $(2.02)$ & $(0.94)$ & (0.6) & $(0.84)$ & $(0.84)$ & $(1.87)$ & $(0.97)$ & $(0.99)$ & $(2.48)$ \\
\hline \multirow[t]{2}{*}{ Over 65} & $0.033^{\mathrm{a}}$ & -0.001 & -0.000 & 0.003 & 0.000 & $-0.006^{\mathrm{a}}$ & $-0.004^{\mathrm{a}}$ & 0.003 & -0.002 & -0.002 & -0.005 & $-.017^{\mathrm{a}}$ \\
\hline & $(5.06)$ & (0.3) & $(0.1)$ & $(1.23)$ & $(0.13)$ & $(3.04)$ & $(2.55)$ & (1.03) & $(0.67)$ & $(0.77)$ & $(1.72)$ & (2.61) \\
\hline
\end{tabular}




\begin{tabular}{|c|c|c|c|c|c|c|c|c|c|c|c|c|}
\hline \multicolumn{13}{|c|}{$\begin{array}{l}\text { Number of male household } \\
\text { Members between age of }\end{array}$} \\
\hline \multirow[t]{2}{*}{$0-5$} & $0.01^{\mathrm{a}}$ & -0.002 & -0.003 & -0.000 & $0.003^{\mathrm{a}}$ & $0.002^{\mathrm{b}}$ & 0.000 & 0.001 & -0.002 & -0.002 & -0.001 & $-0.007^{\mathrm{a}}$ \\
\hline & $(3.32)$ & (1.4) & $(1.52)$ & $(0.43)$ & (3.2) & (2.07) & $(0.67)$ & (1.38) & (1.13) & $(1.82)$ & $(0.67)$ & (2.39) \\
\hline \multirow[t]{2}{*}{ 6-11 } & 0.004 & $0.003^{\mathrm{b}}$ & 0.003 & -0.000 & -0.000 & 0.000 & -0.000 & 0.002 & 0.002 & -0.002 & -0.002 & $-0.011^{\mathrm{a}}$ \\
\hline & $(1.58)$ & $(2.25)$ & (1.49) & $(0.46)$ & $(0.6)$ & $(0.64)$ & $(0.1)$ & (1.64) & $(1.08)$ & (1.79) & $(1.35)$ & (3.97) \\
\hline \multirow[t]{2}{*}{$12-17$} & $0.01^{\mathrm{a}}$ & -0.003 & 0.000 & 0.001 & -0.002 & -0.000 & -0.001 & -0.000 & 0.003 & -0.000 & -0.001 & $-0.006^{\mathrm{b}}$ \\
\hline & (3.4) & (1.88) & $(0.42)$ & (1.3) & (1.77) & $(0.76)$ & $(1.71)$ & $(0.56)$ & $(1.81)$ & $(0.77)$ & $(0.77)$ & (2.19) \\
\hline \multirow[t]{2}{*}{$18-65$} & 0.001 & -0.001 & 0.00 & 0.000 & $0.005^{\mathrm{a}}$ & -0.000 & -0.000 & 0.000 & -0.001 & -0.001 & -0.001 & -0.002 \\
\hline & $(0.68)$ & $(0.9)$ & $(0.53)$ & $(0.48)$ & (5.98) & $(0.38)$ & $(0.62)$ & $(0.12)$ & $(1.2)$ & $(1.36)$ & $(0.98)$ & (1.13) \\
\hline \multirow[t]{2}{*}{ Over 65} & $0.02^{\mathrm{a}}$ & -0.007 & 0.004 & 0.003 & -0.000 & $0.008^{\mathrm{a}}$ & -0.002 & 0.001 & 0.004 & 0.000 & $0.008^{\mathrm{a}}$ & $-0.022^{\mathrm{a}}$ \\
\hline & $(2.95)$ & $(1.82)$ & $(0.87)$ & (1.0) & $(0.19)$ & (3.64) & $(1.45)$ & $(0.04)$ & $(1.06)$ & $(0.07)$ & $(2.54)$ & $(3.41)$ \\
\hline \multicolumn{13}{|c|}{ Expenditure } \\
\hline & -0.002 & $-.005^{\mathrm{a}}$ & $0.004^{\mathrm{a}}$ & 0.001 & $-.004^{\mathrm{a}}$ & $-.005^{\mathrm{a}}$ & $-0.003^{\mathrm{a}}$ & $0.003^{\mathrm{a}}$ & 0.003 & $0.007^{\mathrm{a}}$ & $-.017^{\mathrm{a}}$ & 0.017 \\
\hline & $(0.87)$ & (3.28) & (2.6) & $(0.64)$ & $(3.67)$ & (6.04) & $(4.85)$ & $(2.76)$ & (1.88) & $(6.54)$ & (13.23) & $(4.82)$ \\
\hline
\end{tabular}




\begin{tabular}{|c|c|c|c|c|c|c|c|c|c|c|}
\hline \multicolumn{11}{|c|}{ Price Coefficients } \\
\hline \multirow[t]{2}{*}{ Maize } & $0.018^{\mathrm{a}}$ & & & & & & & & & \\
\hline & $(9.82)$ & & & & & & & & & \\
\hline \multirow[t]{2}{*}{ Rice } & 0.000 & 0.001 & & & & & & & & \\
\hline & $(0.95)$ & $(1.42)$ & & & & & & & & \\
\hline \multicolumn{11}{|c|}{ Other Cereals } \\
\hline & $-0.007^{\mathrm{a}}$ & 0.000 & $0.013^{\mathrm{a}}$ & & & & & & & \\
\hline & $(7.53)$ & $(0.35)$ & (13.06) & & & & & & & \\
\hline \multirow[t]{2}{*}{ Pulses } & 0.000 & 0.000 & -0.000 & $0.004^{\mathrm{a}}$ & & & & & & \\
\hline & $(0.39)$ & $(1.29)$ & $(0.64)$ & $(9.45)$ & & & & & & \\
\hline \multirow[t]{2}{*}{ Dairy } & -0.001 & $0.001^{\mathrm{b}}$ & $-0.002^{\mathrm{a}}$ & $0.001^{\mathrm{a}}$ & -0.000 & & & & & \\
\hline & $(1.58)$ & $(2.21)$ & $(5.77)$ & $(3.01)$ & $(0.85)$ & & & & & \\
\hline \multirow[t]{2}{*}{ Sugar } & -0.000 & -0.000 & 0.000 & 0.000 & $0.001^{\mathrm{b}}$ & $0.002^{\mathrm{a}}$ & & & & \\
\hline & $(0.84)$ & $(1.73)$ & $(0.2)$ & $(0.08)$ & $(2.14)$ & $(6.01)$ & & & & \\
\hline \multirow[t]{2}{*}{ Oil } & $-0.001^{\mathrm{b}}$ & -0.000 & 0.00 & -0.000 & $0.001^{\mathrm{a}}$ & -0.001 & $0.004^{\mathrm{a}}$ & & & \\
\hline & (2.1) & $(1.82)$ & $(0.42)$ & $(1.68)$ & $(3.48)$ & $(4.61)$ & $(20.5)$ & & & \\
\hline \multirow[t]{2}{*}{ Fish } & 0.000 & 0.000 & $-0.001^{\mathrm{a}}$ & $-0.001^{\mathrm{a}}$ & 0.000 & 0.000 & $-0.001^{\mathrm{a}}$ & $0.006^{\mathrm{a}}$ & & \\
\hline & $(1.17)$ & $(1.01)$ & (3.09) & (3.3) & $(0.96)$ & $(0.2)$ & $(4.3)$ & (13.85) & & \\
\hline \multirow[t]{2}{*}{ Starch } & $0.027^{\mathrm{a}}$ & $-0.001^{\mathrm{a}}$ & $0.001^{\mathrm{a}}$ & $-0.001^{\mathrm{a}}$ & 0.000 & $-0.001^{\mathrm{a}}$ & 0.000 & $-0.001^{\mathrm{b}}$ & $0.007^{\mathrm{a}}$ & \\
\hline & $(2.87)$ & $(2.59)$ & $(2.57)$ & $(4.0)$ & $(1.2)$ & (3.96) & $(0.71)$ & $(2.09)$ & $(7.83)$ & \\
\hline \multicolumn{11}{|c|}{ Fruits \& Vegetables } \\
\hline & $-0.001^{\mathrm{a}}$ & -0.00 & $-0.002^{\mathrm{a}}$ & $-0.001^{\mathrm{a}}$ & 0.000 & 0.000 & $-0.001^{\mathrm{a}}$ & $-0.001^{\mathrm{a}}$ & $-0.001^{\mathrm{a}}$ & $0.008^{\mathrm{a}}$ \\
\hline & $(2.38)$ & $(0.8)$ & $(5.41)$ & $(2.54)$ & $(0.54)$ & $(0.3)$ & $(3.98)$ & $(4.61)$ & $(2.35)$ & (15.92) \\
\hline
\end{tabular}




\begin{tabular}{|c|c|c|c|c|c|c|c|c|c|c|c|c|}
\hline Meat & $\begin{array}{l}-0.002^{\mathrm{a}} \\
(2.68)\end{array}$ & $\begin{array}{l}-.002^{\mathrm{a}} \\
(3.4)\end{array}$ & $\begin{array}{l}-0.000 \\
(1.43)\end{array}$ & $\begin{array}{r}-0.001^{\mathrm{a}} \\
(3.39)\end{array}$ & $\begin{array}{l}0.000 \\
(1.15)\end{array}$ & $\begin{array}{l}0.000 \\
(0.78)\end{array}$ & $\begin{array}{l}-0.000 \\
(0.08)\end{array}$ & $\begin{array}{l}-0.000 \\
(1.13)\end{array}$ & $\begin{array}{l}-0.002^{\mathrm{a}} \\
(3.76)\end{array}$ & $\begin{array}{l}0.000 \\
(0.18)\end{array}$ & $\begin{array}{l}0.008^{\mathrm{a}} \\
(11.7)\end{array}$ & \\
\hline \multicolumn{13}{|c|}{ Other foods } \\
\hline & $(9.04)$ & $(0.92)$ & $(0.18)$ & $(1.25)$ & $(1.23)$ & $(0.35)$ & $(2.75)$ & $(2.75)$ & (3.8) & $(0.95)$ & $(0.03)$ & $(6.98)$ \\
\hline \multicolumn{13}{|c|}{ Milk Ratio } \\
\hline & $(16.87)$ & (19.38) & (15.38) & $(18.5)$ & (3.7) & (19.09) & (24.34) & (19.63) & (17.77) & (11.84) & $(19.01)$ & - \\
\hline Adj. $R^{2}$ & 0.20 & 0.21 & 0.13 & 0.11 & 0.05 & 0.17 & 0.23 & 0.12 & 0.21 & 0.12 & 0.18 & - \\
\hline \multicolumn{13}{|c|}{ Model Variance } \\
\hline & 0.021 & 0.07 & 0.01 & 0.003 & 0.003 & 0.002 & 0.001 & 0.064 & 0.097 & 0.063 & 0.075 & - \\
\hline
\end{tabular}

Note: Figures in parenthesis are absolute $t$-ratios. Superscripts a and b indicate statistical significance at 99 and 95 percent level, respectively. 
Table 3: Own-Price and Expenditure Elasticities for Food in Tanzania

\begin{tabular}{|c|c|c|c|c|}
\hline Type of Expenditure & $\begin{array}{c}\text { Marshallian } \\
\text { Elasticity }\end{array}$ & $\begin{array}{l}\text { Absolute } \\
t \text {-ratio }\end{array}$ & $\begin{array}{l}\text { Hicksian } \\
\text { Elasticity }\end{array}$ & $\begin{array}{l}\text { Absolute } \\
t \text {-ratio }\end{array}$ \\
\hline \multicolumn{5}{|l|}{ Maize Demand } \\
\hline Maize & $-0.900^{\mathrm{a}}$ & 86.72 & $-0.713^{\mathrm{a}}$ & 71.52 \\
\hline Expenditure & $0.988^{\mathrm{a}}$ & 74.48 & & \\
\hline $\begin{array}{l}\text { Marginal Expenditure Share } \\
\text { Rice Demand }\end{array}$ & 0.185 & & & \\
\hline Rice & $-0.981^{\mathrm{a}}$ & 94.42 & $-0.887^{\mathrm{a}}$ & 86.18 \\
\hline Expenditure & $0.951^{\mathrm{a}}$ & 64.04 & & \\
\hline Marginal Expenditure Share & 0.093 & & & \\
\hline \multicolumn{5}{|l|}{ Other Cereals Demand } \\
\hline Other Cereals & $-0.846^{\mathrm{a}}$ & 68.20 & $1.053^{\mathrm{a}}$ & 62.28 \\
\hline Expenditure & $1.053^{\mathrm{a}}$ & 51.34 & & \\
\hline \multicolumn{5}{|l|}{ Pulses Demand } \\
\hline Pulses & $-0.924^{\mathrm{a}}$ & 116.00 & $-0.865^{\mathrm{a}}$ & 106.55 \\
\hline Expenditure & $1.012^{\mathrm{a}}$ & 54.87 & & \\
\hline Marginal Expenditure Share & 0.058 & & & \\
\hline \multicolumn{5}{|l|}{ Dairy Demand } \\
\hline Dairy & $-1.012^{\mathrm{a}}$ & 55.48 & $-0.987^{\mathrm{a}}$ & 54.69 \\
\hline Expenditure & $0.869^{\mathrm{a}}$ & 24.25 & & \\
\hline $\begin{array}{l}\text { Marginal Expenditure Share } \\
\text { Sugar Demand }\end{array}$ & 0.024 & & & \\
\hline Sugar & $-0.951^{\mathrm{a}}$ & 130.28 & $-0.903^{\mathrm{a}}$ & 124.05 \\
\hline Expenditure & $0.905^{\mathrm{a}}$ & 57.31 & & \\
\hline Marginal Expenditure Share & 0.047 & & & \\
\hline \multicolumn{5}{|l|}{ Oils Demand } \\
\hline Oils & $-0.885^{\mathrm{a}}$ & 162.04 & $0.851^{\mathrm{a}}$ & 156.10 \\
\hline Expenditure & $0.915^{\mathrm{a}}$ & 52.50 & & \\
\hline \multicolumn{5}{|l|}{ Fish Demand } \\
\hline Fish & $-0.905^{\mathrm{a}}$ & 127.86 & $-0.839^{\mathrm{a}}$ & 118.42 \\
\hline Expenditure & $1.049^{\mathrm{a}}$ & 59.43 & & \\
\hline \multicolumn{5}{|l|}{ Starch Demand } \\
\hline Starch & $-0.910^{\mathrm{a}}$ & 74.68 & $-0.827^{\mathrm{a}}$ & 69.24 \\
\hline Expenditure & $1.039^{\mathrm{a}}$ & 49.43 & & \\
\hline Marginal Expenditure Share & 0.082 & & & \\
\hline \multicolumn{5}{|l|}{ Fruits \& Veget. Demand } \\
\hline Fruits \& Veget. & $-0.913^{\mathrm{a}}$ & 152.36 & $1.079^{\mathrm{a}}$ & 137.38 \\
\hline Expenditure & $1.079^{\mathrm{a}}$ & 89.59 & & \\
\hline Marginal Expenditure Share & 0.097 & & & \\
\hline Meat Demand & & & & \\
\hline Meat & $-0.900^{\mathrm{a}}$ & 127.32 & $-0.820^{\mathrm{a}}$ & -116.21 \\
\hline
\end{tabular}




\begin{tabular}{llcll} 
Expenditure & $0.823^{\mathrm{a}}$ & 61.71 & & \\
Marginal Expenditure Share & 0.079 & & \\
Other Foods Demand & & & \\
Other Foods & $-0.894^{\mathrm{a}}$ & 210.17 & $-0.753^{\mathrm{a}}$ & 42.51 \\
Expenditure & $1.143^{\mathrm{a}}$ & & & \\
Marginal Expenditure Share & 0.141 & & & \\
\hline
\end{tabular}

Note: Superscripts a and b indicate statistical significance at 99 and 95 percent level, respectively. 
Table 4: Cross-Price Elasticities for Food in Tanzania

\begin{tabular}{|c|c|c|c|c|}
\hline Type of Expenditure & $\begin{array}{c}\text { Marshallian } \\
\text { Elasticity }\end{array}$ & $\begin{array}{c}\text { Absolute } \\
t \text {-ratio }\end{array}$ & $\begin{array}{l}\text { Hicksian } \\
\text { Elasticity }\end{array}$ & $\begin{array}{c}\text { Absolute } \\
t \text {-ratio }\end{array}$ \\
\hline \multicolumn{5}{|l|}{ Maize Demand } \\
\hline Rice & 0.006 & 1.13 & $0.103^{\mathrm{a}}$ & 19.98 \\
\hline Other Cereals & $-0.039^{a}$ & 7.13 & $0.044^{\mathrm{a}}$ & 8.34 \\
\hline Pulses & 0.002 & 0.58 & $0.060^{\mathrm{a}}$ & 17.25 \\
\hline Dairy & -0.005 & 1.46 & $0.023^{\mathrm{a}}$ & 6.54 \\
\hline Sugar & -0.002 & 0.62 & $0.050^{\mathrm{a}}$ & 17.05 \\
\hline Oil & -0.004 & 1.86 & $0.032^{\mathrm{a}}$ & 14.94 \\
\hline Fish & 0.005 & 1.36 & $0.066^{\mathrm{a}}$ & 19.68 \\
\hline Starch & $0.016^{\mathrm{a}}$ & 2.96 & $0.094^{\mathrm{a}}$ & 18.40 \\
\hline Fruits \& Vegetables & $-0.008^{\mathrm{b}}$ & 2.01 & $0.082^{\mathrm{a}}$ & 22.37 \\
\hline Meat & $-0.010^{\mathrm{a}}$ & 2.34 & $0.086^{\mathrm{a}}$ & 20.37 \\
\hline Other Foods & $-0.049^{a}$ & 8.44 & $0.073^{\mathrm{a}}$ & 12.98 \\
\hline \multicolumn{5}{|l|}{ Rice Demand } \\
\hline Maize & 0.019 & 1.79 & $0.198^{\mathrm{a}}$ & 19.98 \\
\hline Other Cereals & 0.007 & 0.90 & $0.086^{\mathrm{a}}$ & 12.19 \\
\hline Pulses & 0.009 & 1.89 & $0.065^{\mathrm{a}}$ & 13.08 \\
\hline Dairy & $0.013^{\mathrm{a}}$ & 2.44 & $0.040^{\mathrm{a}}$ & 7.71 \\
\hline Sugar & -0.005 & 1.13 & $0.045^{\mathrm{a}}$ & 10.15 \\
\hline Oils & -0.004 & 1.23 & $0.031^{\mathrm{a}}$ & 9.88 \\
\hline Fish & 0.008 & 1.66 & $0.067^{\mathrm{a}}$ & 14.42 \\
\hline Starch & $-0.014^{b}$ & 1.97 & $0.061^{\mathrm{a}}$ & 9.01 \\
\hline Fruits \& vegetables & 0.000 & 0.03 & $0.086^{\mathrm{a}}$ & 16.29 \\
\hline Meat & $-0.015^{\mathrm{a}}$ & 2.56 & $0.077^{\mathrm{a}}$ & 20.37 \\
\hline Other Foods & 0.012 & 1.72 & $0.129^{\mathrm{a}}$ & 12.98 \\
\hline \multicolumn{5}{|l|}{ Other Cereals Demand } \\
\hline Maize & $-0.100^{\mathrm{a}}$ & 7.57 & $0.099^{\mathrm{a}}$ & 8.34 \\
\hline Rice & -0.002 & 0.27 & $0.101^{\mathrm{a}}$ & 12.19 \\
\hline Pulses & -0.007 & 1.19 & 0.055 & 9.49 \\
\hline Dairy & $-0.035^{\mathrm{a}}$ & 5.94 & 0.005 & 0.88 \\
\hline Sugar & -0.002 & 0.36 & $0.054^{\mathrm{a}}$ & 10.87 \\
\hline Oils & -0.000 & 0.11 & $0.038^{\mathrm{a}}$ & 10.62 \\
\hline Fish & $-0.021^{\mathrm{a}}$ & 3.64 & $0.045^{\mathrm{a}}$ & 8.07 \\
\hline Starch & $0.017^{\mathrm{c}}$ & 1.88 & $0.100^{\mathrm{a}}$ & 12.14 \\
\hline Fruits \& vegetables & $-0.038^{a}$ & 5.97 & $0.058^{\mathrm{a}}$ & 9.50 \\
\hline Meat & $-0.015^{\mathrm{b}}$ & 2.12 & $0.087^{\mathrm{a}}$ & 12.58 \\
\hline Other Foods & -0.005 & 0.53 & $0.125^{\mathrm{a}}$ & 13.90 \\
\hline \multicolumn{5}{|l|}{ Pulses Demand } \\
\hline Maize & 0.002 & 0.18 & $0.193^{\mathrm{a}}$ & 17.25 \\
\hline Rice & 0.010 & 1.12 & $0.109^{\mathrm{a}}$ & 13.08 \\
\hline Other cereals & -0.006 & 0.73 & $0.078^{\mathrm{a}}$ & 9.49 \\
\hline Dairy & $0.017^{\mathrm{a}}$ & 2.91 & $0.047^{\mathrm{a}}$ & 7.86 \\
\hline Sugar & -0.000 & 0.04 & $0.053^{\mathrm{a}}$ & 10.58 \\
\hline Oils & -0.006 & 1.77 & $0.031^{\mathrm{a}}$ & 8.55 \\
\hline Fish & $-0.019^{\mathrm{a}}$ & 3.40 & $0.045^{\mathrm{a}}$ & 8.15 \\
\hline Starch & $-0.033^{\mathrm{a}}$ & 4.01 & $0.047^{\mathrm{a}}$ & 5.99 \\
\hline Fruits \& vegetables & $-0.016^{\mathrm{a}}$ & 2.62 & $0.075^{\mathrm{a}}$ & 12.37 \\
\hline Meat & $-0.025^{\mathrm{a}}$ & 3.47 & $0.074^{\mathrm{a}}$ & 10.69 \\
\hline Other Foods & -0.012 & 1.37 & $0.113^{\mathrm{a}}$ & 13.63 \\
\hline
\end{tabular}




\begin{tabular}{|c|c|c|c|c|}
\hline Dairy Demand & & & & \\
\hline Maize & -0.012 & 0.49 & $0.152^{\mathrm{a}}$ & 6.54 \\
\hline Rice & $0.052^{\mathrm{a}}$ & 2.88 & $0.137^{\mathrm{a}}$ & \\
\hline Other Cereals & $-0.088^{a}$ & 5.01 & -0.015 & \\
\hline Pulses & $0.044^{\mathrm{a}}$ & 3.69 & $0.095^{\mathrm{a}}$ & 7.86 \\
\hline Sugar & $0.030^{\mathrm{a}}$ & 2.74 & $0.076^{\mathrm{a}}$ & 6.96 \\
\hline Oils & $0.032^{\mathrm{a}}$ & 4.06 & $0.064^{\mathrm{a}}$ & 8.24 \\
\hline Fish & 0.019 & 1.67 & $0.073^{\mathrm{a}}$ & 6.43 \\
\hline Starch & 0.030 & 1.79 & $0.099^{\mathrm{a}}$ & 6.01 \\
\hline Fruits\& vegetables & 0.019 & 1.42 & $0.097^{\mathrm{a}}$ & 7.49 \\
\hline Meat & $0.029^{\mathrm{b}}$ & 2.00 & $0.114^{\mathrm{a}}$ & 7.86 \\
\hline Other Foods & -0.013 & 0.54 & $0.094^{\mathrm{a}}$ & 3.96 \\
\hline Sugar demand & & & & \\
\hline Maize & 0.009 & 0.82 & $0.180^{\mathrm{a}}$ & 17.05 \\
\hline Rice & -0.005 & 0.58 & $0.084^{\mathrm{a}}$ & 10.15 \\
\hline Other cereals & 0.010 & 1.18 & $0.085^{\mathrm{a}}$ & 10.87 \\
\hline Pulses & 0.006 & 1.09 & $0.059^{\mathrm{a}}$ & 10.58 \\
\hline Dairy & $0.015^{\mathrm{a}}$ & 2.57 & $0.041^{\mathrm{a}}$ & 6.96 \\
\hline Oils & $-0.012^{\mathrm{a}}$ & 3.60 & $0.020^{\mathrm{a}}$ & 5.62 \\
\hline Fish & 0.007 & 1.33 & $0.064^{\mathrm{a}}$ & 12.18 \\
\hline Starch & $-0.022^{\mathrm{a}}$ & 2.88 & $0.049^{\mathrm{a}}$ & 6.56 \\
\hline Fruits\& vegetables & 0.010 & 1.69 & $0.092^{\mathrm{a}}$ & 15.38 \\
\hline Meat & $0.014^{\mathrm{b}}$ & 2.10 & $0.102^{\mathrm{a}}$ & 15.21 \\
\hline Other Foods & 0.015 & 1.72 & $0.126^{\mathrm{a}}$ & 15.13 \\
\hline Oil Demand & & & & \\
\hline Maize & 0.007 & 0.62 & $0.166^{\mathrm{a}}$ & 14.95 \\
\hline Rice & -0.007 & 0.81 & $0.083^{\mathrm{a}}$ & 9.88 \\
\hline Other cereals & 0.011 & 1.25 & $0.087^{\mathrm{a}}$ & 10.62 \\
\hline Pulses & -0.005 & 0.82 & $0.049^{\mathrm{a}}$ & 8.55 \\
\hline Dairy & $0.023^{\mathrm{a}}$ & 3.83 & $0.050^{\mathrm{a}}$ & 8.24 \\
\hline Sugar & $-0.021^{\mathrm{a}}$ & 3.98 & $0.013^{\mathrm{a}}$ & 2.53 \\
\hline Fish & $0.018^{\mathrm{a}}$ & 3.31 & $0.039^{\mathrm{a}}$ & 7.20 \\
\hline Starch & 0.012 & 1.52 & $0.085^{\mathrm{a}}$ & 10.78 \\
\hline Fruits\& vegetables & $-0.017^{\mathrm{a}}$ & 2.61 & $0.066^{\mathrm{a}}$ & 10.74 \\
\hline Meat & 0.008 & 1.09 & $0.096^{\mathrm{a}}$ & 14.07 \\
\hline Other Foods & -0.011 & 1.35 & $0.101^{\mathrm{a}}$ & 12.50 \\
\hline Fish Demand & & & & \\
\hline Maize & 0.003 & 0.25 & $0.201^{\mathrm{a}}$. & 19.68 \\
\hline Rice & 0.003 & 0.35 & $0.106^{\mathrm{a}}$ & 14.42 \\
\hline Other cereals & $-0.027^{\mathrm{a}}$ & 3.52 & $0.060^{\mathrm{a}}$ & 8.07 \\
\hline Pulses & $-0.020^{\mathrm{a}}$ & 3.88 & $0.042^{\mathrm{a}}$ & 8.15 \\
\hline Dairy & 0.004 & 0.68 & $0.034^{\mathrm{a}}$ & 6.43 \\
\hline Sugar & -0.001 & 0.21 & $0.038^{\mathrm{a}}$ & 8.57 \\
\hline Oils & $-0.016^{\mathrm{a}}$ & 4.78 & $0.023^{\mathrm{a}}$ & 7.20 \\
\hline Starch & $-0.019^{a}$ & 2.54 & $0.064^{\mathrm{a}}$ & 8.89 \\
\hline Fruits\& vegetables & $-0.029^{a}$ & 5.28 & $0.065^{\mathrm{a}}$ & 11.94 \\
\hline Meat & -0.012 & 1.86 & $0.090^{\mathrm{a}}$ & 14.69 \\
\hline Other Foods & $-0.029^{\mathrm{a}}$ & 3.37 & $0.100^{\mathrm{a}}$ & 12.24 \\
\hline
\end{tabular}




\begin{tabular}{|c|c|c|c|c|}
\hline \multicolumn{5}{|l|}{ Starch Demand } \\
\hline Maize & $0.027^{\mathrm{b}}$ & 2.13 & $0.224^{\mathrm{a}}$ & 18.40 \\
\hline Rice & $-0.026^{\mathrm{a}}$ & 2.97 & $0.076^{\mathrm{a}}$ & 9.01 \\
\hline Other cereals & $0.019^{\mathrm{b}}$ & 2.13 & $0.106^{\mathrm{a}}$ & 12.14 \\
\hline Pulses & $-0.026^{\mathrm{a}}$ & 4.42 & $0.035^{\mathrm{a}}$ & 5.99 \\
\hline Dairy & 0.006 & 0.99 & $0.036^{\mathrm{a}}$ & 6.01 \\
\hline Sugar & $-0.021^{\mathrm{a}}$ & 4.21 & $0.017^{\mathrm{a}}$ & 3.38 \\
\hline Oils & -0.001 & 0.31 & $0.039^{\mathrm{a}}$ & 10.78 \\
\hline Fish & $-0.014^{\mathrm{a}}$ & 2.49 & $0.051^{\mathrm{a}}$ & 8.89 \\
\hline Fruits\& vegetables & $-0.018^{\mathrm{a}}$ & 2.81 & $0.076^{\mathrm{a}}$ & 12.25 \\
\hline Meat & $-0.030^{\mathrm{a}}$ & 4.19 & $0.071^{\mathrm{a}}$ & 9.98 \\
\hline Other Foods & $-0.048^{\mathrm{a}}$ & 4.12 & $0.080^{\mathrm{a}}$ & 7.16 \\
\hline Fruits \& Vegetables I & & & & \\
\hline Maize & $-0.033^{\mathrm{a}}$ & 4.11 & $0.171^{\mathrm{a}}$ & 22.37 \\
\hline Rice & $-0.012^{b}$ & 2.04 & $0.094^{\mathrm{a}}$ & 16.29 \\
\hline Other cereals & $-0.037^{\mathrm{a}}$ & 6.27 & $0.053^{\mathrm{a}}$ & 9.50 \\
\hline Pulses & $-0.015^{\mathrm{a}}$ & 3.67 & $0.048^{\mathrm{a}}$ & 12.37 \\
\hline Dairy & -0.000 & 0.01 & $0.031^{\mathrm{a}}$ & 7.49 \\
\hline Sugar & $-0.002^{\mathrm{a}}$ & 5.22 & $0.038^{\mathrm{a}}$ & 10.79 \\
\hline Oils & $-0.013^{\mathrm{a}}$ & 4.97 & $0.027^{\mathrm{a}}$ & 10.74 \\
\hline Fish & $-0.022^{\mathrm{a}}$ & 5.72 & $0.045^{\mathrm{a}}$ & 11.98 \\
\hline Starch & $-0.019^{\mathrm{a}}$ & 3.43 & $-0.066^{\mathrm{a}}$ & 12.25 \\
\hline Meat & -0.007 & 1.36 & $0.098^{\mathrm{a}}$ & 20.83 \\
\hline Other Foods & -0.005 & 0.98 & $0.128^{\mathrm{a}}$ & 26.97 \\
\hline Meat Demand & & & & \\
\hline Maize & 0.011 & 1.31 & $0.167^{\mathrm{a}}$ & 20.37 \\
\hline Rice & -0.003 & 0.51 & $0.167^{\mathrm{a}}$ & 12.92 \\
\hline Other cereals & 0.006 & 1.01 & $0.075^{\mathrm{a}}$ & 12.58 \\
\hline Pulses & -0.004 & 0.91 & $0.044^{\mathrm{a}}$ & 10.69 \\
\hline Dairy & $0.010^{\mathrm{b}}$ & 2.30 & $0.034^{\mathrm{a}}$ & 7.86 \\
\hline Sugar & $0.009^{\mathrm{a}}$ & 2.54 & $0.040^{\mathrm{a}}$ & 10.85 \\
\hline Oils & $0.006^{\mathrm{a}}$ & 2.38 & $0.037^{\mathrm{a}}$ & 14.07 \\
\hline Fish & 0.007 & 1.64 & $0.058^{\mathrm{a}}$ & 14.69 \\
\hline Starch & -0.008 & 1.30 & $0.057^{\mathrm{a}}$ & 9.98 \\
\hline Fruits \& Vegetables & $0.017^{\mathrm{a}}$ & 3.71 & $0.091^{\mathrm{a}}$ & 20.83 \\
\hline Other Foods & $0.022^{\mathrm{a}}$ & 3.22 & $0.123^{\mathrm{a}}$ & 18.78 \\
\hline Other Foods Demand & & & & \\
\hline Maize & $-0.105^{\mathrm{a}}$ & 1.21 & $0.111^{\mathrm{a}}$ & 12.98 \\
\hline Rice & -0.009 & 1.43 & $0.103^{\mathrm{a}}$ & 18.64 \\
\hline Other cereals & -0.011 & 1.64 & $0.085^{\mathrm{a}}$ & 13.90 \\
\hline Pulses & $-0.013^{\mathrm{a}}$ & 3.08 & $0.053^{\mathrm{a}}$ & 13.63 \\
\hline Dairy & -0.011 & 1.95 & $0.022^{\mathrm{a}}$ & 3.96 \\
\hline Sugar & 0.038 & 1.06 & $0.038^{\mathrm{a}}$ & 10.67 \\
\hline Oils & $0.030^{\mathrm{a}}$ & 4.42 & $0.030^{\mathrm{a}}$ & 12.50 \\
\hline Fish & 0.030 & 4.42 & $0.030^{\mathrm{a}}$ & 12.50 \\
\hline Starch & 0.051 & 4.47 & $0.051^{\mathrm{a}}$ & 12.24 \\
\hline Fruits \& Vegetables & $0.039^{\mathrm{a}}$ & 5.11 & $0.052^{\mathrm{a}}$ & 7.16 \\
\hline Meat & $-0.010^{\mathrm{b}}$ & 2.19 & $0.094^{\mathrm{a}}$ & 26.97 \\
\hline Other Food & $-0.014^{\mathrm{b}}$ & 2.31 & $0.097^{\mathrm{a}}$ & 18.78 \\
\hline
\end{tabular}

Note: Superscripts a and b indicate statistical significance at 99 and 95 percent level, respectively. 